\title{
UMA ANTROPOLOGIA DO ESPAÇO
}

\section{Resenha de CHOAY, Françoise. Pour une anthropologie de l'espace. Paris: Seuil, 2006.}

\section{Amilcar Torrão Filho}

Pontifícia Universidade Catótolica de São Paulo

Françoise Choay é bem conhecida do público brasileiro, por vários de seus livros e artigos já traduzidos para o português, como $A$ regra e o modelo, ou a Alegoria do Patrimônio. Este livro, recém-publicado na França, não é exatamente uma obra nova, mas a coletânea de trabalhos esparsos e de difícil acesso, coligidos para a coleção La Couleur des Idées, da editora Seuil. Embora escritos ou publicados entre 1985 e 2005, seus textos apresentam uma incômoda atualidade.

A própria autora, em seu prefácio, chama a atenção para a heterogeneidade dos temas tratados, mas adverte, o que a leitura confirma, que seus textos possuem uma "dupla unidade de objeto e de tempo" (p. 7). Uma unidade de temas, pois para ela edifícios singulares e arquitetura, cidades e urbanismo, monumentos e conservação patrimonial, projetos icônicos e projeto político, são formas e práticas múltiplas de uma mesma e única atividade, "cujo desdobramento no espaço natural permite às sociedades humanas edificar o seu meio próprio" (pp. 7-8). E uma unidade temporal, não necessariamente de suas balizas cronológicas, que vão do século XV de Alberti ao século XXI do patrimônio mundial, mas do período no qual estão inseridos os textos escolhidos, que a autora afirma estar marcado por uma revolução eletro-telemática, ou informacional, de enorme impacto sobre a cidade, o urbanismo e o patrimônio.

O livro está dividido em quatro partes: História e Crítica, O Urbano, Patrimônio e Antropologia; ainda que sejamos advertidos que esta classificação é em parte arbitrária, e estes temas se entrecruzem constantemente. Justamente a antropologia, que dá título ao volume, dá uma unidade conceitual a estes textos aparentemente heterogêneos. A autora insiste nesta "função antropo-genética da espacialização" que, segundo ela, está totalmente ausente 
do debate sobre a arquitetura e o urbanismo, mesmo nos órgãos de administração ou na "praça pública", unânimes em "celebrar o caráter lúdico e mediático de todas as 'artes do espaço', devotados "ao deus da moda e das finanças" (p. 10). Ou seja, Choay procura destacar o caráter não-natural da arquitetura e da produção de cidades, nos quais a política e a ação do homem são constitutivas, muito mais do que uma técnica pretensamente científica e neutra.

Sua primeira crítica é endereçada, então, a Le Corbusier, num texto que o coloca em perspectiva. Seu interesse não é tanto a obra de Le Corbusier, como um determinado aporte moderno sobre a arquitetura e a cidade, representada pelo arquiteto suíço. Tampouco são as carências técnicas de suas obras construídas, embora não deixe de apontá-las; mas demonstrar o que denomina "a dimensão retórica do funcionalismo corbusiano" (p. 16). Justamente porque esta dimensão retórica é o aspecto mais importante da obra do arquiteto, responsável pelo que Choay considera a sua incompreensão da condição antropológica da urbanização; ou mais claramente, a ausência de uma dimensão verdadeiramente urbana de seus projetos de metrópoles (p. 21). A dimensão polemista de seus textos, mais abundantes que sua obra construída, e sua recepção altamente midiática, seriam responsáveis pelo alcance de seu trabalho no pensamento urbanístico, a despeito de sua incompreensão da real dimensão da técnica na cidade, ao contrário dos esquecidos Ildefonso Cerdà, que Choay não se cansa de recuperar, e Gustavo Giovannoni, ou de Camillo Sitte, acusado pelo mesmo Jeanneret de passadista.

Apoiado numa ideologia progressista, Le Corbusier presume, assim, a universalidade das necessidades do homem, por isso a possibilidade de se construir as suas famosas "máquinas de morar" e "máquinas de habitar"; mais do que isso, "trata-se de conceber, para o homem universal, protótipos reprodutíveis de cidades e não mais apenas edifícios isolados" (p. 25). Trata-se de uma modernidade universalizante e "desumana", destinada a um "homem teórico", portanto inexistente (p. 36). Mas o arquiteto suíço não é o único representante desta ideologia progressista, composta de "imperativos categóricos, de paralogismos, de amálgamas terminológicos, de referências a saberes não dominados, de metáforas falaciosas", cujos autores se instauram 
como "detentores e enunciadores da verdade arquitetônica e urbanística"; dos quais o mais talentoso, e midiático, é hoje Rem Koolhas (p. 115).

Falta-nos, para Choay, um discurso crítico e autocrítico, ou um "discurso epistemológico" sobre a cidade e a arquitetura, que ela encontra, por exemplo, em Alberti, daí a unidade de objeto de seu texto apesar da enorme distância temporal. Por isso a sua insistência no caráter não prescritivo do $D e R e$ Aedificatoria, cuja finalidade não é descrever os meios que permitam "realizar uma série de projetos concretos, nem de propor uma coleção de edifícios ideal-típicos, mas de fazer compreender a significação do ato construtivo" ( $p$. 379). Tanto em Le Corbusier como em Alberti, a autora insiste em seu caráter retórico, que não significa obviamente apenas "discurso", numa acepção de senso comum, mas de uma preceptiva do ato de construir, uma teoria da arquitetura e do urbanismo (p. 379). A diferença é que Alberti reconhece a dimensão antropológica da construção de cidades e da vida urbana.

Apesar de acusada, como Sitte e Giovannonni, de passadista, por sua defesa da cidade já construída e do patrimônio arquitetônico, que ela toma o cuidado de distinguir do patrimônio histórico, mais ligado aos "abusos de uma indústria mundializada e mundializante do patrimônio" (p. 319), e que não tem, necessariamente, um "estatuto antropológico" (p. 266), Choay chama a atenção para o que considera um grande anacronismo atual: denominar os espaços urbanos nos quais habitamos hoje pelo conceito arcaico de "cidade" ("Ville": un archaïsme lexical, pp. 148-153). Deveríamos, assim, admitir o desaparecimento da cidade tradicional e interrogar-nos sobre "a natureza da urbanização e sobre a não-cidade que parece ter se tornado o destino das sociedades ocidentais avançadas" (p. 167); o que denomina, baseada em Melvin Webber, de era pós-urbana, título de um dos artigos citados deste autor (p. 200).

Para não deixar dúvidas quanto ao caráter não-passadista de sua obra, chega a sugerir até mesmo algumas demolições vistas como necessárias: da Biblioteca Nacional (ou ironicamente a Très Grand Bibliothèque), por seu "programa anacrônico, concepção anti-funcional, implantação absurda, e custo de funcionamento insano", a Ópera da Bastilha e o Ministério das Finanças, por sua "desestruturação sem apelo do tecido circundante" e inutilidade (p. 304). Claro que, assim como Alberti, seu texto não é prescritivo, nem um manual de construção de cidades. Suas sugestões polêmicas e impossíveis, nestes casos 
citados, são muito mais um destaque sobre a forma como determinadas intervenções urbanas não levam em conta um conhecimento antropológico da cidade e do patrimônio e uma profunda incompreensão da significação do ato construtivo, que ela identifica na obra de Alberti. Um debate premente para o qual, infelizmente, possui poucos interlocutores.

Recebido em 12/09/2007. 